\title{
Assessment of heavy metal residues in water, fish tissue and human blood from Ubeji, Warri, Delta State, Nigeria
}

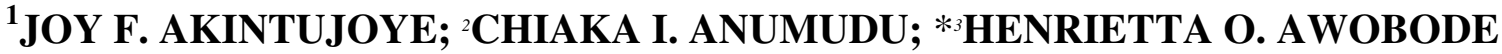

\author{
${ }^{I}$ Ecology and Environmental Biology Unit, Department of Zoology, University of Ibadan, Nigeria \\ Cellular Parasitology Unit, Department of Zoology, University of Ibadan, Nigeria \\ Parasitology Unit, Department of Zoology, University of Ibadan, Nigeria \\ *Corresponding Author Tel: +234 802628100 \\ email: henrie.awobode@ui.edu.ng \\ awobodet@yahoo.com
}

\begin{abstract}
Residual levels of lead, chromium, cadmium and zinc in water and fish tissue from Ubeji River, Warri and blood samples from residents of Ubeji were analysed. Control water and fish samples were obtained from Eleyele River and blood from residents of Ibadan. All the samples collected were digested using a modified procedure from the Association of Official Analytical Chemists (AOAC) and were subsequently analyzed using Atomic Absorption Spectroscopy. Levels of lead and cadmium in Ubeji river were significantly higher than levels in Eleyele River. Fifty fish samples from five species (Citharinus citharus, Liza falcipinis, Brycinus macrolepidotus, Polydactylus quadrifilis and Tilapia zilli) were analysed. Lead concentration (ppm) was highest in C. citharus (76.07 \pm 161.48$)$ and least in T. zilli $(23.16 \pm 26.30)$. Chromium was not detected in B. macrolepidotus, $P$. quadrifilis and T. zilli. Concentrations of all heavy metals detected, except zinc, in the fish species were higher than WHO permissible limit. Lead, Cadmium and Zinc concentrations in the tissues of the control fish were significantly lower $(\mathrm{p}>0.05)$ than those recorded in fish from Ubeji River. There were no statistically significant differences in heavy metal concentration in fish gills and muscle $(\mathrm{p}>0.05)$. Lead and cadmium levels in Ubeji river significantly exceeded $(\mathrm{p}=0.0$ and $\mathrm{p}=0.012)$ the permissible limits for aquaculture and drinking. Levels of Chromium (1737.17 \pm 2996.01$)$, Zinc and Lead $(149.35 \pm 188.28$ and $123.49 \pm 350.85$ respectively) were significantly high $(\mathrm{p}<0.05)$ in the 101 human blood samples screened, while concentrations of Cadmium was comparatively low (10.11 \pm 10.71$)$. Lower levels of cadmium, zinc and lead $(8.54 \pm 7.49,79.89 \pm 62.65$ and 53.46 \pm 57.17 , respectively) were recorded for the control samples from Ibadan. This study highlights the high levels of heavy metals in the Ubeji River and suggests the need for interventions to stem the tide of pollution in the river. It would also be important to assess health problems that may arise as a result of contact and continuous use of the water. @ JASEM
\end{abstract}

DOI: http://dx.doi.org/10.4314/jasem.v17i2.12

Key Words : Heavy metal residues, Fish tissue, Human blood, Ubeji River.

The unselective dumping of refuse, discharge of industrial effluents, petroleum wastes and crude oil spills replete with heavy metals give rise to consequences which are of paramount importance to the health of the environment. These discharged wastes contain heavy metals which, although considered essential macro- and micro-elements especially at non-adverse effect levels (Dimari et al., 2008), may have adverse effects on the population in the concentrations encountered in polluted environments. Metals such as copper and zinc are generally regarded as essential trace metals (Nduka et al., 2010) because of their valuable role in the metabolic activities of organisms. However, heavy metals like Cadmium, Lead, Nickel and Mercury exhibit extreme toxicity even at trace levels. Most essential metals have been found to be toxic when supplied in concentrations in excess of the optimal levels.

Heavy metal contamination of aquatic environments is of critical concern because of their toxicity and accumulation in aquatic organisms. Many dissolved metals entering rivers are adsorbed onto colloid 
particulates; at high alkalinity and $\mathrm{pH}$, the metals particularly lead and cadmium, precipitate by forming complexes, further influencing the metal toxicity (Dimari et al., 2008). Aquatic organisms such as phytoplankton, zooplankton, fishes and other higher organisms, during feeding may incorporate these heavy metals into their bodies where they may remain for a very long time in sea foods. The metals that accumulate in the tissue of the sea food, concentrate to high amount and are passed on in the food chain.

Accumulation of heavy metals in an aquatic environment has direct consequences for man and the ecosystem. The most significant problem associated with heavy metals in the environment apart from accumulation through the food chain and persistence in nature is their toxicity (King and Jonathan, 2003; Dimari et al., 2008). Fishes, being major components of most aquatic habitats have also been recognized as good bio-accumulators of organic and inorganic pollutants (King and Jonathan, 2003). They also act as bio-indicators of heavy metal levels in such environments, and can be used to evaluate the health of such aquatic ecosystems. (Farkas et al., 2002; Yousuf and El-Shahawi, 1999).

The degree to which a system, organ, tissue or cell is affected by a heavy metal depends on the toxin itself and the individuals' degree of exposure to the toxin. Thus, metals contribute to a variety of adverse effects that can impact human health and each will produce different behavioral, physiological and cognitive changes in an exposed individual.

Studies on the Ubeji Creek have mainly been focused on the effect of petrochemical effluents on the water quality (Uzoekwe and Oghosanine, 2011; Asagbra Unpublished dissertation, 2010; Achudume, 2009). It is known that the process of bioaccumulation concentrates metals in some food species which may be hazardous to human health, therefore knowledge of the concentration of metals existing in any aquatic ecosystem is necessary. Since the Warri Refinery and Petrochemical Company (WRPC) discharges wastes into the Ubeji Creek, this study aimed at assessing the levels of metal residues in fish and water from the Ubeji River and in the people living in the environment of Ubeji River.

\section{MATERIALS AND METHODS}

Study Area: Ubeji community is located beside the Warri Refinery and Petrochemical Company
(WRPC) Warri, Delta State, Nigeria. The Ubeji River which runs through the community receives untreated or minimally treated industrial wastes directly from the Warri refinery through the Ubeji Creek. The average atmospheric temperature in Ubeji is $25.5^{\circ} \mathrm{C}$ in the rainy season and $30.1^{\circ} \mathrm{C}$ in the dry season. The daily relative humidity values ranged from $55.5 \%$ in the dry season to $96 \%$ in the rainy season. The occupation of the human population in Ubeji is mainly fishing and they depend on the creek as a major outlet to the larger water body.

Sample Collection : Water samples for this study were collected at two different locations, up and downstream of the Ubeji River. Water was collected in a litre container at a distance of $200 \mathrm{~m}$ between sampling stations (Fig.1). Samples of five fin-fish species (Citharinus citharus, Liza falcipinis, Brycinus macrolepidotus, Polydactylus quadrifilis and Tilapia zilli) collected from both up and downstream on the Ubeji River, were transported frozen to the laboratory for heavy metal analysis.

A total of 101 volunteers were recruited into the study after obtaining their informed consent. The volunteers live and work in Ubeji and are reported to have contact with Ubeji river. Blood $(0.5 \mathrm{ml})$ was collected on labeled filter paper from each person, filter papers were air dried and transported to the University of Ibadan for analysis. The study protocol followed approved ethical procedures for this study as obtained from the UI/UCH research ethics committee. Control (water, fish and human) samples were collected in and around Eleyele River in Ibadan, Nigeria.

Laboratory analysis: Digestion of water samples, $10 \mathrm{ml}$ of nitric acid was added to $50 \mathrm{ml}$ of each water sample and heated at $150^{\circ} \mathrm{C}$ for $30 \mathrm{mins} .5 \mathrm{ml}$ of nitric acid was then added to each tube and heated for 30 minutes at $200^{\circ} \mathrm{C}$, to the mixture was added $2 \mathrm{ml}$ of hydrogen peroxide before further heating at $200^{\circ} \mathrm{C}$ for 30minutes. The resulting solutions were allowed to cool at room temperature and then the volume made up to $25 \mathrm{ml}$ with distilled water (AOAC, 1995).

Digestion of fish samples; Fish samples were analysed by a modified procedure from the Association of Official Analytical Chemists (AOAC, 1995). One gram wet weight each of gill and muscle for each of the fin-fish sample was dried for $8 \mathrm{hrs}$ at $180^{\circ} \mathrm{C} .0 .3 \mathrm{~g}$ of each dried sample was placed separately in labeled test-tubes and $5 \mathrm{ml}$ of a mixture of chloroform-

\section{${ }^{1}$ JOY F. AKINTUJOYE; CHIAKA I. ANUMUDU; *HENRIETTA I. AWOBODE}


methanol-water $(2: 1: 0.5)$ was added to each tube and allowed to stand overnight at room temperature for lipid extraction. The samples were subsequently

Thereafter, $20 \mathrm{ml}$ of de-ionized water was added to each tube to give a final Nitric acid concentration of Lead Cadmium, Zinc and Chromium using Atomic Absorption Spectroscopy, (model-analyst 200, PerkinElmer).

Digestion of blood samples: Blood samples were digested according to the method of Mei et al., (2001). Four punches were made from each of the blood spotted air dried filter papers and transferred into labeled digesting test-tubes. Ten (10) $\mathrm{ml}$ of nitric acid was added to each tube and heated at $150^{\circ} \mathrm{C}$ for 30 mins then another $5 \mathrm{ml}$ of nitric acid was added to each tube and further heated at $200^{\circ} \mathrm{C}$ for $30 \mathrm{mins}$. $2 \mathrm{ml}$ of hydrogen peroxide was subsequently added to each sample and heated at $200^{\circ} \mathrm{C}$ for 30 mins. The solution was allowed to cool and the volume was made up to $25 \mathrm{ml}$ with distilled water to compensate for evaporation.

\section{RESULTS AND DISCUSSION}

The levels of Chromium(Cr), Cadmium(Cd), Lead $(\mathrm{Pb})$ and $\mathrm{Zinc}(\mathrm{Zn})$ in water, fish and human blood samples from Ubeji were determined.

Water Analysis: Lead and Cadmium levels in water samples from Ubeji River were significantly higher than levels recorded in Eleyele River, which served as the control (Table 1). Chromium was not detected in Ubeji River. Lead and cadmium levels were significantly higher in water samples from Ubeji river than in the Eleyele control samples. This is probabaly as a result of heavy metals from crude oil sources, which are main pollutants in Ubeji river.(Achudume 2009) The heavy metal concentrations recorded in Ubeji river were higher than standard limits for portable water and aquaculture (WHO, 1996). Even though there was no indication that inhabitants of Ubeji drink from the river, aquatic life abound in the waters and can bioaccumulate these metals and subsequently transfer it to consumers. This is suggested by the high concentration of these metals recorded both in the fish species collected from the Ubeji river and the blood from the inhabitants of Ubeji who eat the fish from the river.

Heavy metals in fish gills and muscle: The concentrations of $\mathrm{Cd}, \mathrm{Zn}$ and $\mathrm{Pb}$ in the muscle of the five fish species analysed were not significantly washed in de-ionized water before the addition of $5 \mathrm{ml}$ of nitric acid to each tube for sample digestion.

20\%. Digested samples were analyzed for levels of

different $(\mathrm{p}>0.05)$. The mean values for $\mathrm{Pb}(\mathrm{mg} / \mathrm{g})$ were $76.07 ; 35.27 ; 37.8042 .15 ; 23.16$ and 22.72 for Citharinus citharus, Liza falcipinis, Brycinus macrolepidotus, Polydactylus quadrifilis, Tilapia zilli and control samples respectively. Chromium was not detected in B. macrolepidotus, P. quadrifilis and $T$. zilli while mean values recorded in $C$. citharus and $L$. falcipinis were $0.48 \mathrm{mg} / \mathrm{g}$ and $1.60 \mathrm{mg} / \mathrm{g}$ respectively (Figures 1-4).

The pattern of heavy metal accumulation in the gills of the fish species was slightly different from the muscles. There was a highly significant difference in the concentrations of cadmium, zinc and lead recorded in the gill of the five species. Highest concentration of lead and cadmiun was recorded in $B$ macrolepidotus $(47.80 \pm 3.72$ and $5.35 \pm 5.24)$ and the lowest levels $(29.92 \pm 15.01$ and $2.38 \pm 2.25)$ were in Liza falcipinis (Figues1,4). The highest concentration of zinc $(140.76 \pm 105.58)$ was recorded in the gills of C. Citharus and the lowest in L. falcipinis, (61.23 \pm 38.72). There was a significant difference between the values of chromium recorded in $B$. macrolepidotus $\left(\begin{array}{ll}7.80 & \pm 9.81\end{array}\right)$ when compared to concentration in the other species (Figure 3).

When comparing the pattern observed in the gills and muscle, the concentrations of zinc was highest in both gills and muscle of all five fish species, followed by levels of lead (Figures 2). The levels of chromium and cadmium were comparatively lower in the fish samples (Figure1, 3). There was no appreciable significance in lead concentrations in the muscle of the five fish species used in this study; Citharinus citharus had lead levels almost twice the concentration recorded in some of the other fish species in this study. This concentration was also about 50 times higher than the permissible limit of 1.5 ppm, being the FAO/WHO (1984) recommended standard. Moreover, there were differences in the ability of the various fish species to accumulate lead. Tilapia had the least concentration of lead though the value was 15.3 times higher than the permissible limit. This report is similar to that of Obasohan (2007) in which high levels of heavy metals were detected in mudfish from Ogba River, Benin city, Nigeria. The high concentration of lead recorded in

\section{${ }^{1}$ JOY F. AKINTUJOYE; CHIAKA I. ANUMUDU; *HENRIETTA I. AWOBODE}


this study may be due to recurrent oil- based pollutants which are the main sources of pollution to Ubeji River.

All the five fish species examined in this study had heavy metal concentrations higher than the permissible limit by FAO/WHO (1984). This suggests that these fish species may not be suitable for consumption. The variation in the level of heavy metal accumulation in the gills and muscle of the different fish species may support the view that there is a variation in ability of different fish organs to accumulate heavy metals. Vinodhini and Narayanan (2008) found that lead and cadmium accumulation in gills was relatively higher than other metals.

The gill has also been reported as an important site for the entry of heavy metals which provokes lesions and gill damage (Lock and Overbeeke, 1981; Bols et al., 2001). Although Moore and Ramamurthy, (1984) reported that Cadmium is accumulated primarily in major organ tissues of fish rather than in muscles, in this study higher Cadmium concentration was found in the muscle than gills of most of the fish species examined.

Heavy metal concentration in human blood:Analysis of the blood samples collected showed lead levels in $61.39 \%$ of the study participants, cadmium in $75.25 \%$, chromium in $98.01 \%$ and zinc in $99.01 \%$. Chromium levels were significantly higher (1737.17士 2996.01) than the levels of any the other heavy metals $(p<0-05)$, levels of cadmium $(10.11 \pm 10.71)$ were the lowest in the study group (Figure 5). The values of the heavy metals in the human blood in this study were higher than the stipulated permissible levels (WHO 1996).

There were gender-related differences in the concentrations of the metals in the participants. Cadmium $(10.50 \pm 10.68 \mathrm{mg} / \mathrm{g})$ and Lead $(129.73 \pm 440.93 \mathrm{mg} / \mathrm{g})$ levels in males were higher than in female participants $(9.69 \pm 10.84 \mathrm{mg} / \mathrm{g}$ and $116.87 \pm 223.10 \mathrm{mg} / \mathrm{g}$ respectively). Chromium and
Zinc levels were however higher in the females $(1908.50 \pm 105.67 \mathrm{mg} / \mathrm{g}$ and $154.96 \pm 151.14 \mathrm{mg} / \mathrm{g}$ respectively) than in the males $(1575.71 \pm 909.9 \mathrm{mg} / \mathrm{g}$ and 144.06 \pm 218.97$)$. These differences were however not significantly different ( $\mathrm{p}>0.05$ ) for $\mathrm{Cd}, \mathrm{Pb}, \mathrm{Cr}$ and $\mathrm{Zn}$ respectively. The heavy metals except zinc were present in high amounts in the human blood samples, the levels of zinc recorded were below the permissible limit (WHO 1996). The source of the heavy metals detected in human blood in this study location may be linked to bioaccumulation from consumption of fishes from the Ubeji river.

Cadmium levels showed a weak negative, but significant $\quad(\mathrm{p}<0.05)$ correlation with age of participants $(\mathrm{r}=-0.241)$. Cadmium accumulation in human blood may likely reduce with age.

The high levels of the heavy metals from this study further underscore the high level of environmental pollution prevalent in Nigeria as a result of effluents and spillages from the oil and gas industry. Various other studies have reported high levels of environmental pollution in the Nigerian environment (Adekola and Saidu, 2005; Egbereonu and Ozuzu, 2005).

Conclusion:This study reports high level of heavy metal pollution in Ubeji River. The pollution occurs at levels that can constitute serious health problems for the inhabitants of this area. Efforts should be directed towards remediating the water body and stopping the discharge of pollutants from the refinery into the Ubeji river. It may not be out of place for the government to provide alternate source of protein to the inhabitants of Ubeji to reduce their consumption of polluted fish from the river until the water has been cleaned up.

Conflict Of Interest:Authors declare no conflict of interest. Acknowledgement:The authors acknowledge Ubeji community and the study participants for their cooperation.

Table 1: Concentrations of heavy metals in water samples from Ubeji river

\begin{tabular}{|l|l|l|l|l|}
\hline Heavy metal & Test sample $(\mathrm{mg} / \mathrm{L})$ & Control $(\mathrm{mg} / \mathrm{L})$ & $\mathrm{t}$ value & $\mathrm{P}$ value \\
\hline Lead & 0.051 & 0.036 & 8.660 & $0.037^{*}$ \\
\hline Cadmium & 0.045 & 0.036 & 4.191 & $0.012^{*}$ \\
\hline Chromium & ND & 0.037 & -0.611 & 0.325 \\
\hline Zinc & 0.253 & 0.276 & -0.543 & 0.313 \\
\hline
\end{tabular}

ND - Not detected

*Differences in mean values of test samples and control are significantly different $(\mathrm{p}<0.05)$

${ }^{1}$ JOY F. AKINTUJOYE; CHIAKA I. ANUMUDU; *HENRIETTA I. AWOBODE 

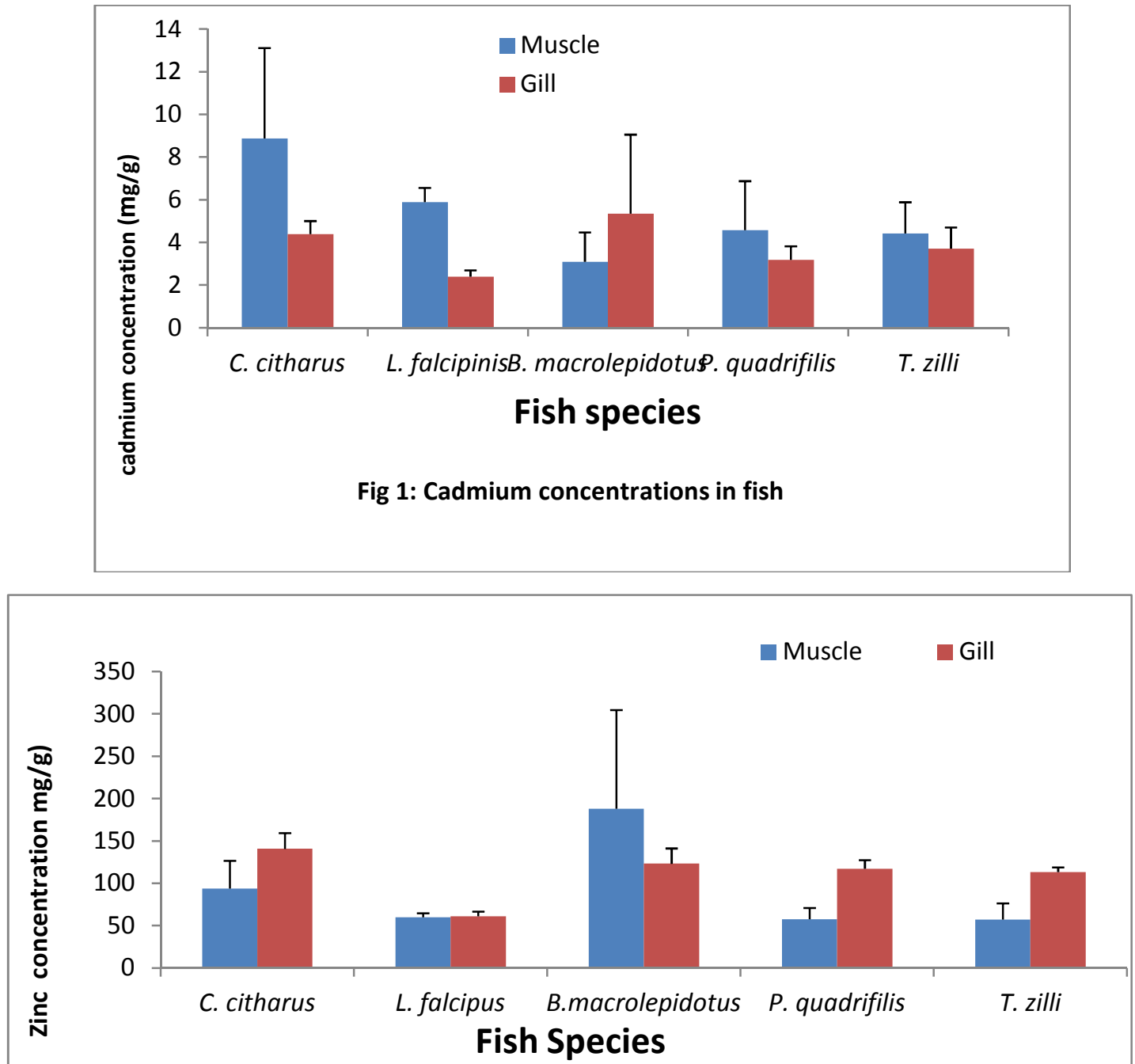

Fig. 2: Zinc concentration in fish species

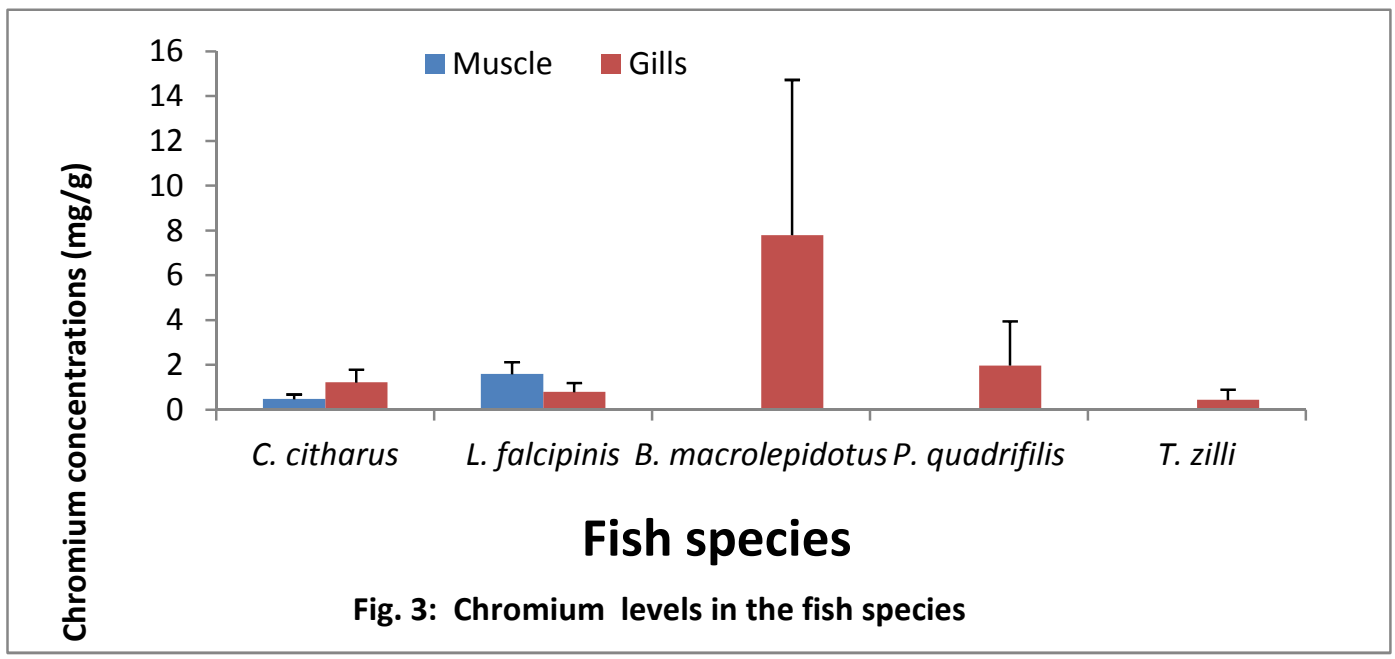

${ }^{1}$ JOY F. AKINTUJOYE; CHIAKA I. ANUMUDU; *HENRIETTA I. AWOBODE 

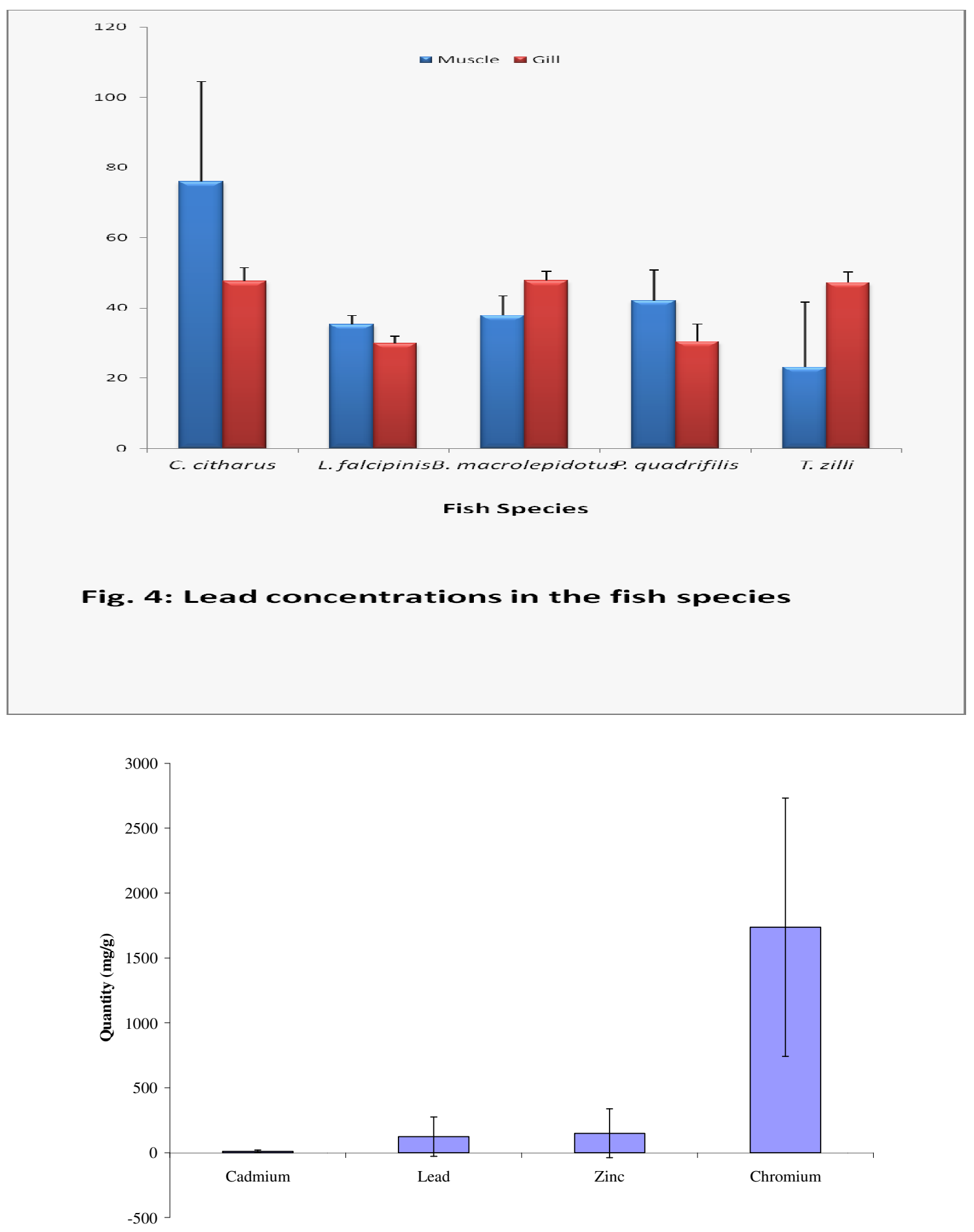

Heavy metals

Fig 4: Heavy metal concentration in human blood from Ubeji 


\section{REFERENCES}

Achudume, A.C. 2009. The effect of petrochemical effluent on the water quality of Ubeji creek in Niger Delta of Nigeria. Bull. Envi Contaminants and Toxicity. 81(3):410-415.

Adekola, F. A. and Saidu, M. M. 2005. Determination of pollution level of water and sediment samples of Landzu River Bida, Nigeria. J. Chem. Soc. Nigeria, 30: 181-186.

Anderson, R. H. and Kozlowsky, A. S. 1985. Chromium intake, absorption and excretion of subjects consuming self- selected diets. American journal of clinical nutrition, 41: 1177- 1183.

Asagbra M.O.(2010) Polycyclic Aromatic Hydrocarbon Analysis and genetic characterization of fin fish species from the Warri River. M.Sc Thesis University of Ibadan

Bols, N. C., Brubacher, J. L., Ganassin, R. C and Lee, L. E. 2001. Ecotoxicology and innate immunity in fish. Dev. Comp. Immunol., 25 (8): 853-873.

Denton, G. R. W. and Burdon-Jones, C. 1986. Trace metals in fish from the Great Barrier Reef. Mar. Pollut. Bull. 17: pp 201-209.

Dimari, G. A., Abdulkarim, F. I., Akan, J. C. and Garba, S.T. 2008. Metal concentrations in Tissues of Tilapia galier, Clarias lazera, and Osteoglosidae caught from Alau Dam, Maiduguri, Borno State, Nigeria. American Journal of Environmental Sciences. 4 (4): 473 - 379.

Egbereonu, U. U. and Ozuzu, C. I. U. 2005. Physiochemical analysis of River Niger at Onitsha bank, Nigeria. J. Chem. Soc. Nig., 30: 197-203.

FAO/WHO. 1984. List of maximum levels recommended for contaminants by the Joint FAO/ WHO Codex Alimentarius Commission. Second Series. CAC/FAL, Rome 3: 1-8.

Farkas, A., Salanki, J.; Specziar, A., (2002). Relation between growth and the heavy metal concentration in organs of bream Abramis brama L. populating lake Balaton. Arch. Environ. Contam. Toxicol., 43 (2), 236243.

Irwandi, J. and Farida, O. 2009. Mineral and heavy metal contents of marine fin fish in Langkawi island, Malaysia. International Food Research Journal 16: 105-112.
King, R. P. and Jonathan, G. E. 2003. Aquatic environment perturbations and monitoring: African experience, USA.

Lock, R. A. and Van Overbeeke, A. P. 1981. Effects of mercuric chloride on mucus secretion in rainbow trout, Salmo gairdneri, Richardson. Comp. Biochem. Phys., 69 (1), 67-73.

Mei, J. V., Alexander, J. R., Adam, B. W. and Hannon, W. H. 2001. Use of filter paper for the collection and analysis of human whole blood specimens. J. Nutr., 131(5): 1631S-1636S.

Moore, J. W. and Ramamoorthy S. 1984. Heavy Metals in Natural waters Applied Monitoring and Impact Assessment. SpringerVerlag, New York, 268 pp.

Nduka J. K., Orisakwe O. E. and Okerulu I. O. 2010. Heavy Metal Levels in Muscles of Some Fish Species from Aladja River; Warri, Nigeria: A Public Health Concern. Advances Environmental Biology, 4(5): 125-130.

Obasohan, E.E., 2007. Heavy metals concentrations in the offal, gill, muscle and liver of a freshwater mudfish (Parachanna obscura) from Ogba River, Benin city Nigeria. Afr. J. Biotechnol., 6: 2620-2627.

Uzoekwe, S. A. and Oghosanine, F.A. 2011. The effect of refinery and petrochemical effluent on water quality of Ubeji creek warri, southern Nigeria. Ethiopian Journal of Environmental Studies and Management Vol. 4 No.2 2011. Pp 1-10.

Vinodhini R. and Narayanan M. (2008) Bioaccumulation of heavy metals in organs of fresh water fish Cyprinus carpio (common carp).Int. J. Environ. Sci. Tech. 5(2) 179-182

WHO, 1996. Trace Elements in Human Nutrition and Health. World Health Organization, Geneva, Switzerland ISBN $92 \quad 4 \quad 156173 \quad 4 \quad$ (NLM Classification: QU 130).

Yousuf, M. H. A.; El-Shahawi., (1999). Trace metals in Lethrinus lentjan fish from Arabian Gulf: Metal accumulation in Kidney and Heart Tissues. Bull. Environ. Contam. Toxicol., 62 (3), 293-300.

${ }^{1}$ JOY F. AKINTUJOYE; CHIAKA I. ANUMUDU; *HENRIETTA I. AWOBODE 